\title{
PENGGUNAAN LINGUISTIK KORPUS DALAM MEMPERSIAPKAN BAHAN AJAR ENGLISH FOR SPECIFIC PURPOSE DI BIDANG RADIOLOGI
}

\author{
Euis Reliyanti Arum ${ }^{1 *}$, Wiwin Winarti ${ }^{1}$ \\ ${ }^{1}$ Politeknik Al Islam Bandung, Jln. Cisaranten Kulon no.120 Bandung \\ *euisreliyanti@politeknikalislam.ac.id
}

\begin{abstract}
ABSTRAK
Minimnya buku ajar English for Specific Purpose (ESP) di bidang radiologi yang sesuai untuk mahasiswa Program Studi Radiologi di Indonesia menjadi tantangan bagi para dosen pengajar Bahasa Inggris di Program Studi Radiologi Politeknik Al Islam Bandung. Untuk mengantisipasi kebutuhan akan bahan ajar ESP tersebut maka dilakukan penelitian linguistik terhadap buku teks radiologi berbahasa Inggris yang digunakan para mahasiswa radiologi selama kuliah dengan menggunakan linguistik korpus sebagai alat untuk mendapatkan kosa kata serta terminologi di bidang radiologi serta gramatika dan fitur kata yang digunakan dalam buku tersebut. Metode yang digunakan dalam penelitian ini adalah metode gabungan dengan mengaplikasikan metode kuantitatif untuk mendapatkan data penelitian dan metode kualitatif pada proses analisis untuk mendapatkan simpulan. Hasil penelitian menunjukkan bahwa terdapat 12.395 kata berbeda yang digunakan dengan total jumlah kata secara keseluruhan termasuk kata yang diulang-ulang adalah sebanyak 428.117 kata. Kata-kata tersebut diklasifikasikan ke dalam kelas kata nomina, verba, ajektiva, adverbia, singkatan, dan lain-lain. Secara garis besar, hasil analisis memperlihatkan penggunaan struktur kalimat aktif dan pasif, auxiliary verbs, countable dan uncountable nouns, comparative degree, serta tenses yang meliputi present, present continuous, past, dan present perfect tenses. Selanjutnya, hasil analisis ini akan digunakan untuk menyusun bahan ajar ESP bidang radiologi. Sementara daftar kata dan terminologi radiologi yang terkumpul akan disusun menjadi sebuah kamus mini buku teks radiologi di atas.
\end{abstract}

Kata kunci: bahan ajar, linguistik korpus, ESP

\begin{abstract}
The limited sources of English for Specific Purpose textbooks relating to the radiology study program that is suitable for radiology students in Indonesia become a challenge for English lecturers at Al Islam Polytechnic of Bandung. To anticipate the need for the ESP textbook, researchers conducted a study on a radiology textbook used by radiology students during their study by using corpus linguistics as a tool to obtain radiological vocabularies as well as grammar and features of the words used in the textbook. This study applied a mixed-method by combining the quantitative method to get the quantitative data of the study and the qualitative method in the analysis process to draw conclusions. The results showed that there were 12,395 different
\end{abstract}


words used in the textbook with a total number of words including repeated words as many as 428,117 words. These words are classified into noun, verb, adjective, and adverb clauses as well as abbreviations and others. Generally, results of the analysis showed the use of active and passive sentences, auxiliary verbs, countable and uncountable nouns, and comparative degree tenses including the simple present, present continuous, past, and present perfect tenses. Furthermore, the results will be used to arrange the textbook of English for Specific Purposes in the field of radiology. Meanwhile, the word list and radiological terminologies will be arranged in a mini dictionary of the radiology textbook.

Keywords: ESP, corpus linguistic, textbook

\section{PENDAHULUAN}

Mata kuliah Bahasa Inggris menjadi salah satu Mata Kuliah Dasar Umum yang wajib diikuti oleh mahasiswa di seluruh perguruan tinggi termasuk di perguruan tinggi vokasi. Berdasarkan tujuannya, Bahasa Inggris di perguruan tinggi dapat diklasifikasikan menjadi Bahasa Inggris umum (General English) dan Bahasa Inggris Khusus (English for Specific Purposes). English for Specific Purposes (ESP) atau Bahasa Inggris untuk tujuan khusus adalah sebuah pendekatan pembelajaran Bahasa Inggris yang khusus berfokus pada penggunaan Bahasa Inggris di bidang keilmuan dan profesi tertentu. Pada dasarnya, secara teori ESP tidak berbeda dengan General English yang selama ini diajarkan di kelas tetapi dalam linguistik terapan ESP memperkenalkan fokus pada pembelajar dengan konteks bidang yang dipelajarinya (Hutchinson \& Waters, 1987). Perbedaan antara ESP dan General English $(G E)$ terlihat dengan jelas dalam hal practice. Pada $G E$ Bahasa Inggris yang diperkenalkan adalah Bahasa Inggris yang biasa digunakan untuk berkomunikasi secara umum kepada semua orang. Ekspresi dan kosa kata yang diajarkan adalah ekspresi yang biasa terjadi dalam kehidupan sehari-hari. Sementara itu, Dudley (1998) memaparkan bahwa kosa kata yang digunakan dalam ESP erat hubungannya dengan bidang kajian dari keilmuan yang dipelajari dan profesi yang ditekuni.

Dengan demikian, maka bahan ajar ESP di Politeknik Al Islam terutama di Program Studi Radiologi tentu saja harus berisi kosa kata dan terminologi yang biasa digunakan di bidang radiologi serta penggunaannya sesuai dengan profesi radiografer. Sayangnya, di Indonesia bahan ajar ESP radiologi yang sesuai dengan kemampuan mahasiswa Indonesia sangat terbatas. Karenanya, penelitian untuk mengetahui fitur linguistik dari buku teks radiologi yang meliputi kosa kata, terminology, dan tata bahasanya perlu dilakukan. Berdasarkan kebutuhan tersebut, maka rumusan permasalahan pada penelitian ini fokus pada kosa kata dan terminologi serta fitur linguistik kata-kata yang digunakan pada buku teks radiologi yang berjudul Radiographic Positioning and Related Anatomy karya Bontrager and Lampignano.

Buku Radiographic Positioning and Related Anatomy merupakan buku radiologi yang wajib dimiliki oleh setiap mahasiswa di Program Studi Radiologi. Buku ini menjadi buku panduan yang digunakan oleh mahasiswa radiologi selama kuliah di Politeknik Al Islam Bandung. Dengan jumlah halaman 826, pada intinya buku ini berisi daftar dan definisi patologi umum untuk memahami kondisi pasien dan menghasilkan radiograf yang jelas, anatomi, ketentuan positioning, aturan proyeksi, kriteria evaluasi untuk setiap proyeksi, dan indikasi klinis yang menjelaskan mengapa proyeksi diperlukan atau patologi apa yang ditunjukkan untuk memahami alasan di balik setiap proyeksi. Dengan informasi yang lengkap seperti itu maka dapat dipastikan bahwa terminologi dan kosa kata Bahasa Inggris yang diperlukan oleh para mahasiswa Program Studi Radiologi dapat digali dari buku tersebut. 
Tujuan penelitian ini adalah untuk mengetahui kosa kata, terminology, dan tata bahasa yang digunakan dalam buku teks radiologi. Hasil penelitian akan digunakan dalam penyusunan bahan ajar ESP untuk Program Studi Radiologi dan kamus mini buku teks Radiographic Positioning and Related Anatomy yang selain akan bermanfaat untuk memudahkan mahasiswa dalam memahami buku teks tersebut, juga akan membantu mereka dalam memahami teks dan jurnal berbahasa Inggris di bidang radiologi. Sehingga tidak hanya akan memudahkan para mahasiswa menyelesaikan kuliahnya dengan baik tapi juga akan bermanfaat saat mereka bekerja.

\section{METODOLOGI PENELITIAN}

Penelitian ini dilakukan di Politeknik Al Islam Bandung pada tahun 2019. Metode yang digunakan pada penelitian ini adalah metode campuran ( $m i x$ method) di mana pada awal penelitian metode yang digunakan adalah metode kuantitatif yang berfungsi untuk mendapatkan data yang akan diteliti dan pada proses analisis menggunakan metode kualitatif. Pada tahap awal, metode kuantitatif digunakan untuk mendapatkan data kuantitatif yang dilakukan dengan bantuan perangkat lunak konkordansi Ant Conc. Buku teks radiologi dalam bentuk pdf dikonversi ke dalam bentuk plain text supaya dapat diproses oleh Ant Conc. Melalui fitur frekuensi pada perangkat ini dihasilkan daftar seluruh kata yang digunakan di dalam buku tersebut berdasarkan kekerapan kemunculannya mulai dari yang paling sering muncul sampai kata yang hanya satu kali muncul. Daftar yang dihasilkan software kemudian dipilah pada proses reduksi untuk memisahkan kata yang bermakna penuh dan kata-kata lain seperti singkatan, potongan suku kata, ataupun angka. Selanjutnya kata yang bermakna penuh diklasifikasikan ke dalam kelas kata masing-masing sesuai dengan fungsinya dalam kalimat. Setelah didapat data yang sudah terpilih, maka kata-kata tersebut lalu dianalisis secara kualitatif untuk mengetahui fitur linguistik yang menempel pada masing-masing kelas kata untuk kemudian diambil kesimpulannya. Secara ringkas alir penelitian ini dapat digambarkan dengan diagram berikut ini. 


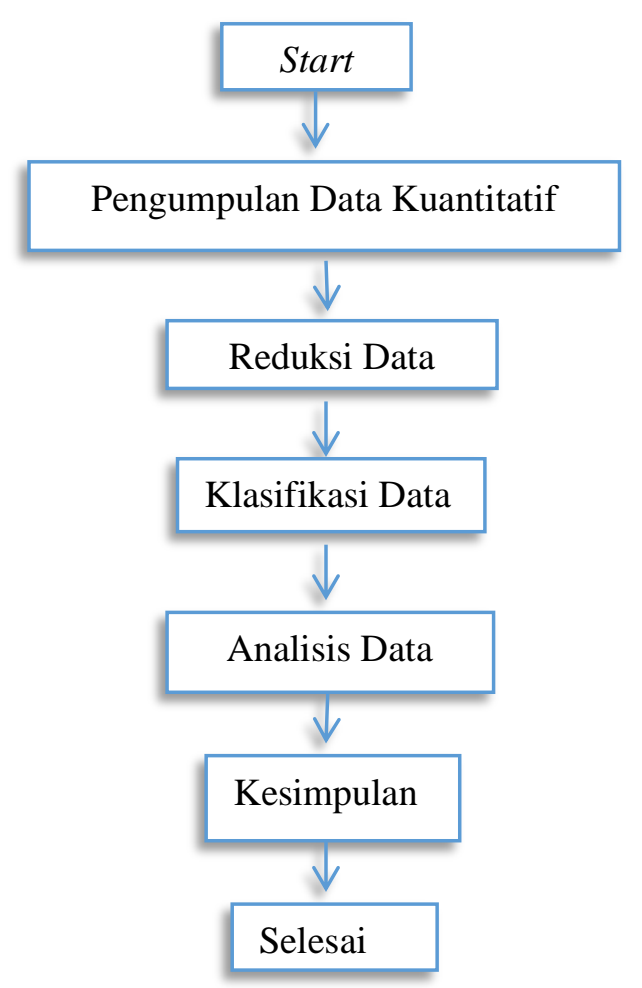

Gambar 1. Diagram Alir Penelitian

\section{Linguistik Korpus}

Berdasarkan bentuk dan tujuannya, Hunston (2002:2) mendefinisikan 'korpus' sebagai kumpulan contoh bahasa alami, yang terdiri dari beberapa kalimat dari satu rangkaian teks tertulis atau rekaman-rekaman yang telah dikumpulkan untuk studi linguistik. Teks dalam bentuk bahasa lisan maupun bahasa tulis tersebut kemudian disusun secara sistematis. Korpus dikatakan "alami" karena teks yang dikumpulkan adalah teks yang diproduksi dan digunakan secara wajar dan tidak dibuat-buat (apa adanya). Teks-teks tersebut diantaranya berupa buku ajar, jurnal, buku teks, novel, koran, majalah, rekaman siaran pembicaraan, hasil wawancara, dan banyak lagi.

Linguistik korpus oleh ahli bahasa McEnery \& Wilson (2001) dijelaskan sebagai sebuah sistem yang menyeluruh berisi metode dan prinsip-prinsip untuk mengaplikasikan korpus dalam penelitian bahasa dan pengajaran atau pembelajaran. Sementara itu Hardie (2012) mendefinisikan linguistik korpus sebagai sebuah bidang yang fokus pada serangkaian prosedur atau metode untuk mempelajari bahasa. Berdasarkan definisi tersebut, dapat disimpulkan bahwa linguistik korpus adalah penelitian bahasa yang menggunakan contoh-contoh bahasa sehari-hari atau alami yang tersimpan dalam korpus.

Yang menjadi korpus dalam penelitian ini adalah buku teks Radiographic Positioning and Related Anatomy. Linguistik korpus cocok diterapkan pada penelitian ini, karena linguistik korpus memiliki fitur yang dibutuhkan untuk mencapai tujuan penelitian. Fitur linguistik tersebut adalah: 


\section{Frekuensi}

Frekuensi atau kekerapan pada linguistik korpus mengacu pada jumlah kemunculan suatu kata dalam sebuah korpus atau teks (McEnery dan Hardie, 2011). Tidak hanya digunakan untuk menghitung kemunculan pada kata-kata tunggal, frekuensi juga memungkinkan dilakukannya penghitungan frekuensi gramatikal, semantis, atau kategori lainnya. Frekuensi juga dapat membimbing peneliti untuk mendapatkan temuan yang lebih luas.

Frekuensi dalam linguistik korpus menunjukkan hitungan berapa kali sebuah kata muncul dalam sebuah korpus. Analisis frekuensi memungkinkan peneliti mengenali kata-kata yang paling sering muncul di korpus tertentu, dan kemudian membandingkan dan membedakannya dengan kata-kata lain. Pada penelitian ini, frekuensi digunakan untuk mengetahui kosa kata dan terminologi di bidang radiologi yang sering muncul yang perlu diketahui oleh mahasiswa untuk dapat memahami buku tersebut. Sehingga mahasiswa mengetahui daftar kosa kata dan terminologi yang menjadi prioritas untuk dihafalkan dan difahami. Selain itu, dengan diketahuinya kata yang lebih sering muncul secara otomatis menunjukan fitur linguistik apa yang menjadi prioritas untuk diajarkan kepada mahasiswa raadiologi.

\section{Konkordansi}

Konkordansi merupakan daftar atau urutan contoh-contoh dari kata, bagian dari kata atau kombinasi kata yang berada dalam konteksnya yang diambil dari korpus teks (Baker, et. al., 2012). Kata utama yang menjadi tujuan pencarian dalam korpus disebut kata kunci (keyword). Banyak cara untuk menampilkan kata kunci tersebut. Salah satu cara yang paling banyak digunakan dalam korpus linguistik adalah penggunaan kata kunci dalam konteks atau dikenal dengan KWIC (key word in context). Konkordansi merupakan aspek penting dari linguistik korpus yang memungkinkan berlangsungnya analisis kualitatif yang akan dilakukan pada data korpus. Hal ini memungkinkan peneliti mengeksplorasi kasus-kasus individu secara rinci. Analisis konkordansi biasanya penting dilakukan sebelum kita bisa membuat klaim tentang variasi bahasa atau perubahan berdasarkan frekuensi.

Untuk menampilkan suatu konkordansi diperlukan bantuan perangkat lunak yang bertugas menyelidiki item linguistik tertentu dalam konteksnya dengan mempertimbangkan kata-kata di sekitarnya yang mungkin berkisar dari satu kata ke kiri atau kanan dari item tersebut ke keseluruhan teks jika diperlukan (McEnery \& Wilson, 2001). Teknik konkordansi ini juga memungkinkan peneliti untuk melakukan analisis kualitatif dengan cara memungkinkan mereka mempelajari item tersebut dalam teks yang menyertainya.

Pada penelitian ini, teknik konkordansi diterapkan untuk membantu berlangsungnya proses analisis kualitatif pada data yang sudah tersedia. Analisis data dilakukan untuk melihat fitur linguistik yang menempel pada sebuah kata selain dengan melihat bentuk kata itu sendiri juga melihat kata-kata disekelilingnya. Melalui teknik konkordansi akan diketahui seperti kelas kata dari sebuah kata, tenses yang digunakan apakah dia past tense, present perfect, atau jenis kalimat aktif atau pasif. 


\section{HASIL DAN PEMBAHASAN}

\section{Hasil Ant Conc}

Pada tahap awal, buku teks radiologi dalam bentuk PDF dikonversi ke dalam dokumen dalam bentuk plain file. Hal ini dilakukan supaya buku tersebut dapat diproses dalam software konkordansi Ant Conc. Melalui fitur wordlist dokumen diproses oleh software tersebut dan menghasilkan daftar kata yang terdapat dalam buku radiologi itu berdasarkan frekuensi kekerapannya (jumlah kemunculannya) sesuai dengan linguistik korpus.

Tabel 1. Daftar 100 kata hasil proses Ant Conc berdasarkan kekerapannya (Frek.)

\begin{tabular}{|c|c|c|c|c|c|}
\hline \multicolumn{6}{|c|}{$\begin{array}{l}\text { \#Word Types: } 12395 \\
\text { \#Word Tokens: } 428117\end{array}$} \\
\hline No. & Frek & Leksikal & No. & Frek & Leksikal \\
\hline 1. & 26790 & the & 51. & 845 & Inches \\
\hline 2. & 18389 & of & 52. & 834 & It \\
\hline 3. & 11777 & and & 53. & 823 & These \\
\hline 4. & 10824 & $\mathrm{x}$ & 54. & 804 & $\mathrm{~Pa}$ \\
\hline 5. & 9560 & to & 55. & 801 & No \\
\hline 6. & 7120 & is & 56. & 795 & Anatomy \\
\hline 7. & 6193 & $\mathrm{a}$ & 57. & 769 & Posterior \\
\hline 8. & 5776 & fig & 58. & 766 & Left \\
\hline 9. & 5623 & in & 59. & 757 & $\mathrm{Ct}$ \\
\hline 10. & 4615 & for & 60. & 727 & Head \\
\hline 11. & 4381 & or & 61. & 718 & Digital \\
\hline 12. & 3573 & $\mathrm{f}$ & 62. & 709 & Collimation \\
\hline 13. & 3355 & with & 63. & 704 & $\mathrm{R}$ \\
\hline 14. & 3294 & image & 64. & 700 & Joints \\
\hline 15. & 3137 & be & 65. & 694 & $\mathrm{Kv}$ \\
\hline 16. & 2956 & are & 66. & 693 & $\mathrm{Xd}$ \\
\hline 17. & 2669 & as & 67. & 670 & Into \\
\hline 18. & 2577 & patient & 68. & 664 & Spine \\
\hline 19. & 2470 & on & 69. & 660 & Oblique \\
\hline 20. & 2207 & lateral & 70. & 658 & Anterior \\
\hline 21. & 1957 & that & 71. & 655 & Upper \\
\hline 22. & 1935 & position & 72. & 649 & Lower \\
\hline 23. & 1835 & this & 73. & 646 & Distal \\
\hline 24. & 1739 & ir & 74. & 646 & Part \\
\hline 25. & 1637 & $\mathrm{cr}$ & 75. & 630 & Rotation \\
\hline 26. & 1606 & by & 76. & 629 & Also \\
\hline 27. & 1424 & ap & 77. & 626 & $\mathrm{~L}$ \\
\hline 28. & 1347 & an & 78. & 620 & Demonstrated \\
\hline 29. & 1345 & from & 79. & 613 & Interest \\
\hline 30. & 1344 & may & 80. & 608 & Bones \\
\hline 31. & 1319 & should & 81. & 606 & Small \\
\hline 32. & 1271 & $\mathrm{xb}$ & 82. & 606 & System \\
\hline 33. & 1139 & $\mathrm{~cm}$ & 83. & 602 & Two \\
\hline 34. & 1130 & exposure & 84. & 595 & Radiographic \\
\hline 35. & 1064 & joint & 85. & 592 & Area \\
\hline 36. & 1061 & at & 86. & 583 & Through \\
\hline
\end{tabular}




\begin{tabular}{llcllc}
\hline 37. & 1040 & contrast & 87. & 577 & Range \\
\hline 38. & 1036 & $\mathrm{c}$ & 88. & 575 & Each \\
\hline 39. & 1032 & projection & 89. & 574 & During \\
\hline 40. & 1019 & $\mathrm{t}$ & 90. & 567 & Positioning \\
\hline 41. & 1008 & $\mathrm{~s}$ & 91. & 561 & Side \\
\hline 42. & 972 & imaging & 92. & 560 & Most \\
\hline 43. & 965 & body & 93. & 545 & Procedure \\
\hline 44. & 940 & if & 94. & 542 & Process \\
\hline 45. & 933 & not & 95. & 540 & Because \\
\hline 46. & 930 & bone & 96. & 539 & Factors \\
\hline 47. & 927 & which & 97. & 536 & Barium \\
\hline 48. & 915 & used & 98. & 535 & Region \\
\hline 49. & 876 & can & 99. & 534 & Use \\
\hline 50. & 846 & right & 100. & 531 & Chest \\
\hline
\end{tabular}

Word types menunjukkan jenis kata secara individu yang digunakan pada buku itu. Jumlah kata yang digunakan adalah sebanyak 12.395 kata yang kemudian akan direduksi, diklasifikasikan, dan dianalisis. Sementara itu words token adalah jumlah kata secara keseluruhan yang ada di buku itu termasuk kata-kata yang diulang atau dengan kata lain words token adalah total seluruh kata hasil dari penjumlahan kekerapan tiap kata. Jadi buku radiologi setebal 826 halaman itu berisi total 428.177 kata.

\section{Reduksi Data}

Pada tahap ini peneliti memusatkan perhatian pada data lapangan yang telah terkumpul. Data lapangan berupa daftar kata berdasarkan kekerapan kemunculannya tersebut selanjutnya direduksi dengan cara memisahkan kata yang bermakna penuh dengan kata-kata lainnya. Pada tahap reduksi ini selain kata yang bermakna penuh, juga berhasil dikumpulkan daftar kata yang berupa singkatan, potongan kata, dan lain-lain. Tahap reduksi menentukan derajat relevansinya dengan tujuan penelitian.

Tabel 2. Contoh daftar kata dasar

\begin{tabular}{ccc}
\hline No & Kekerapan & Kata Dasar \\
\hline 1 & 3294 & image \\
\hline 2 & 2577 & patient \\
\hline 3 & 2207 & lateral \\
\hline 4 & 1935 & position \\
\hline 5 & 1130 & exposure \\
\hline 6 & 1064 & joint \\
\hline 7 & 1040 & contrast \\
\hline 8 & 1032 & projection \\
\hline 9 & 972 & Imaging \\
\hline 10 & 965 & Body \\
\hline 11 & 930 & Bone \\
\hline 12 & 915 & Used \\
\hline 13 & 845 & Inches \\
\hline 14 & 795 & Anatomy \\
\hline 15 & 769 & Posterior \\
\hline 16 & 766 & Left \\
\hline & &
\end{tabular}




\begin{tabular}{ccc}
\hline 17 & 727 & Head \\
\hline 18 & 718 & Digital \\
\hline 19 & 709 & Collimation \\
\hline 20 & 664 & Spine \\
\hline 21 & 660 & Oblique \\
\hline 22 & 658 & Anterior \\
\hline 23 & 655 & Upper \\
\hline 24 & 649 & Lower \\
\hline 25 & 646 & Distal \\
\hline
\end{tabular}

Tabel 3. Contoh singkatan

\begin{tabular}{|c|c|c|}
\hline No & Kekerapan & Singkatan \\
\hline 1 & 5776 & Fig. \\
\hline 2 & 1739 & IR \\
\hline 3 & 1637 & CR \\
\hline 4 & 1424 & AP \\
\hline 5 & 1139 & $\mathrm{CM}$ \\
\hline 6 & 804 & PA \\
\hline 7 & 801 & $\mathrm{NO}$ \\
\hline 8 & 757 & $\mathrm{CT}$ \\
\hline 9 & 694 & $\mathrm{KV}$ \\
\hline 10 & 361 & MRI \\
\hline 11 & 336 & SID \\
\hline 12 & 129 & $\mathrm{RAO}$ \\
\hline 13 & 127 & LPO \\
\hline 14 & 93 & IVU \\
\hline 15 & 78 & OML \\
\hline 16 & 78 & vs. \\
\hline 17 & 72 & LAO \\
\hline 18 & 69 & MCP \\
\hline 19 & 66 & EAM \\
\hline 20 & 64 & AEC \\
\hline 21 & 62 & $\mathrm{~mA}$ \\
\hline 22 & 60 & BMD \\
\hline 23 & 59 & IOML \\
\hline 24 & 54 & MSP \\
\hline 25 & 52 & Fx \\
\hline
\end{tabular}

Tabel 4. Contoh daftar kata yang terpotong

\begin{tabular}{ccc}
\hline No & Kekerapan & Potongan Kata \\
\hline 1 & 30 & warnin- \\
\hline 2 & 29 & -butor \\
\hline 3 & 24 & -de \\
\hline 4 & 23 & ko- \\
\hline 5 & 21 & -cation \\
\hline 6 & 22 & -raphy \\
\hline 7 & 22 & -tion \\
\hline 8 & 21 & -ng \\
\hline 9 & 20 & -ry \\
\hline 10 & 18 & -ar \\
\hline
\end{tabular}




\section{Klasifikasi Data}

Pada tahap ini, peneliti melakukan klasifikasi terhadap data terpilih yang merupakan kata dasar yang bermakna (contoh tabel 2). Klasifikasi dilakukan dengan memilih dan memisahkan daftar kata tersebut berdasarkan kelas katanya masing-masing. Kata-kata tersebut diklasifikasikan berdasarkan teori dari Gelderen (2010) yang menjelaskan bahwa leksikal kategori (kelas kata) dalam Bahasa Inggris secara sintaksis terbagi menjadi 5 kategori yaitu Noun/Nomina $(\mathrm{N})$, Verba/Verb (V), Ajektiva/Adjective (Adj), Adverbia/Adverb (Adv), dan Kata Depan /Preposition (P).

Tabel 5. Contoh daftar kata berdasarkan kelas katanya masing-masing

\begin{tabular}{|c|c|c|c|}
\hline NO & KELAS KATA & CONTOH KATA & JUMLAH KATA \\
\hline 1 & $\begin{array}{l}\text { Kata Benda } \\
\text { (Noun) }\end{array}$ & $\begin{array}{l}\text { Image, patient, position, exposure, joint, contrast, } \\
\text { projection, they, imaging, body, bone, inches, } \\
\text { anatomy, head, collimation, our, spine, part, } \\
\text { rotation, system } \\
\text { Pronoun: They, she, we, you, your, our, us, him, } \\
\text { them, him, him }\end{array}$ & \\
\hline 2 & $\begin{array}{l}\text { Kata Kerja } \\
\text { (Verb) }\end{array}$ & $\begin{array}{l}\text { is, be, are, used, demonstrated, positioning, see, } \\
\text { view, include, erect, has, shown, recommended, } \\
\text { performed, placed, ensure, called, taken, described, } \\
\text { required, been, located, processes, centered, study, } \\
\text { collimate, visualized, }\end{array}$ & \\
\hline 3 & $\begin{array}{l}\text { Kata sifat } \\
\text { (Adjective) }\end{array}$ & $\begin{array}{l}\text { Lateral, right, posterior, left, digital, oblique, } \\
\text { anterior, upper, lower, distal, small, two, } \\
\text { radiographic, each, most, more, can, axial, clinical, } \\
\text { proximal, common, other, possible, one }\end{array}$ & \\
\hline 4 & $\begin{array}{l}\text { Kata Keterangan } \\
\text { (Adverb) }\end{array}$ & $\begin{array}{l}\text { slightly, posteriorly, anteriorly, laterally, } \\
\text { radiographically, carefully, internally, firmly, often, } \\
\text { usually, sometimes, always, frequently, only, so, } \\
\text { very, well, too, greatly, completely, partially, } \\
\text { approximately, now, weekly, annually, previously, } \\
\text { upward, backward, downward, outside, }\end{array}$ & \\
\hline 5 & $\begin{array}{l}\text { Kata Depan } \\
\text { (Preposition) }\end{array}$ & $\begin{array}{l}\text { Of, to, in, for, with, on, by, at, into, through, during, } \\
\text { between, within, under, after, before, about, up, } \\
\text { over, above, below, toward }\end{array}$ & \\
\hline 6 & Singkatan & $\begin{array}{l}\text { Fig., IR, } C R, A P, C M, P A, N O, C T, K V, M R I, \\
S I D, R A O, L P O, I V U, O M L, v S, L A O, M C P, E A M \text {, } \\
A E C, m A, B M D, I O M L, M S P, f x\end{array}$ & \\
\hline 7 & Potongan kata & $\begin{array}{l}\text { warnin-, -butor, -de, ko-, -cation, -raphy, -tion } \\
-n g,-r y,-a r\end{array}$ & \\
\hline 8 & Lain-lain & $\begin{array}{l}\text { Konjungsi: and, or, if, because, when, than, but } \\
\text { Artikel: the, } a \text {, an }\end{array}$ & \\
\hline & & TOTAL & 12.395 \\
\hline
\end{tabular}

Daftar kata yang terkumpul akan digunakan sebagai bahan kosa kata dalam penyusunan buku ajar berkenaan dengan radiological vocabularies serta reading. 


\section{Analisis Data}

Setelah semua data diklasifikasikan berdasarkan kelas katanya, kosa kata yang termasuk ke dalam open class (kata benda, kata sifat, kata kerja, dan kata keterangan) dianalisis secara manual untuk mencari fitur yang melekat pada kata-kata tersebut. Berlandaskan teori yang dikemukakan oleh Gelderen (2010) dan Quirk. at al (1980) maka ditemukan fitur-fitur tiap kelas kata yang dapat disimpulkan sebagai berikut:

Selain dilihat dari maknanya, penggunaan akhiran $-\mathrm{s}$ sebagai penanda nomina tunggal dan jamak, penyebutan nama orang atau tempat, maka dapat disimpulkan bahwa fitur kata benda yang ditemukan pada kelas kata benda adalah:

Countable Noun, contohnya: image, patient, bone, head,

Uncountable noun, contohnya: vision, projection,

Proper Nouns, contohnya: Bontrager, Lampignano

Common Noun, contohnya: machine, patient,

Concrete Noun, contohnya: contrast, apple, cervix

Abstract Noun, contohnya: system, capacity, profession

Ditemukan juga kata ganti nomina (pronoun) seperti they, she, we, you, your, our, us, him, them, him, him, that, this, which, these, who

Dari kata kerja yang terkumpul fitur kata kerja yang didapatkan adalah:

Main verbs: Is, be, are, used, demonstrated, positioning, see, view, include, erect, shown, recommended, performed, placed, ensure, called, taken, described, required, been, located, processes, centered, study, collimate, visualized

Auxiliary verbs: is, are, has, have

Modal auxiliary verbs: can, could, will, would, may, might, shall, should, must

Setelah dilihat kata-kata disekeliling kata kerja tersebut di atas maka disimpulkan adanya jenis kalimat aktif dan kalimat pasif serta tenses berupa Simple present, Simple past, Present continuous, Simple present perfect, juga ditemukan penggunaan gerund serta pola reducing relative clause.

Fitur kata sifat yang muncul dalam bentuk Comparative dan superlative adjectives yang dicirikan dengan penggunaan akhiran -er pada larger, outer, higher dan - est pada closest, lowest, nearest serta adanya penambahan kata more pada more lateral, more common, more painful dan most pada most current, most unique, most effective.

Kata Keterangan (adverbial) yang mucul pada buku radiologi yang diteliti banyak yang berasal dari kata sifat yang diberi akhiran -ly. Jenis adverbial yang ditemukan adalah:

Adverb of manner: slightly, posteriorly, anteriorly, laterally, radiographically, carefully, internally, firmly

Adverb of frequency: often, usually, sometimes, always, frequently,

Adverb of degree: only, so, very, well, too, greatly, completely, partially, approximately

Adverb of time: now, weekly, annually, previously

Adverb of place: upward, backward, downward, outside,

Teras Kesehatan - 9

Selain ke lima kelas kata di atas juga ditemukan kata kategori lain-lain yang tidak termasuk ke dalam ke lima kelas kata tersebut. Pada daftar lain-lain didapat daftar kata yang termasuk ke dalam konjungsi yaitu:

Coordinate conjunction: and, or, but

Subordinate conjunction: although, because 
Correlative conjunction: however

Hasil analisis berupa fitur linguistik di atas akan digunakan sebagai bahan pada penyusunan modul English for Specific Purposes di Program Studi Radiologi Politeknik Al Islam Bandung yang berkaitan dengan tata bahasa Bahasa Inggris Radiologi.

\section{KESIMPULAN}

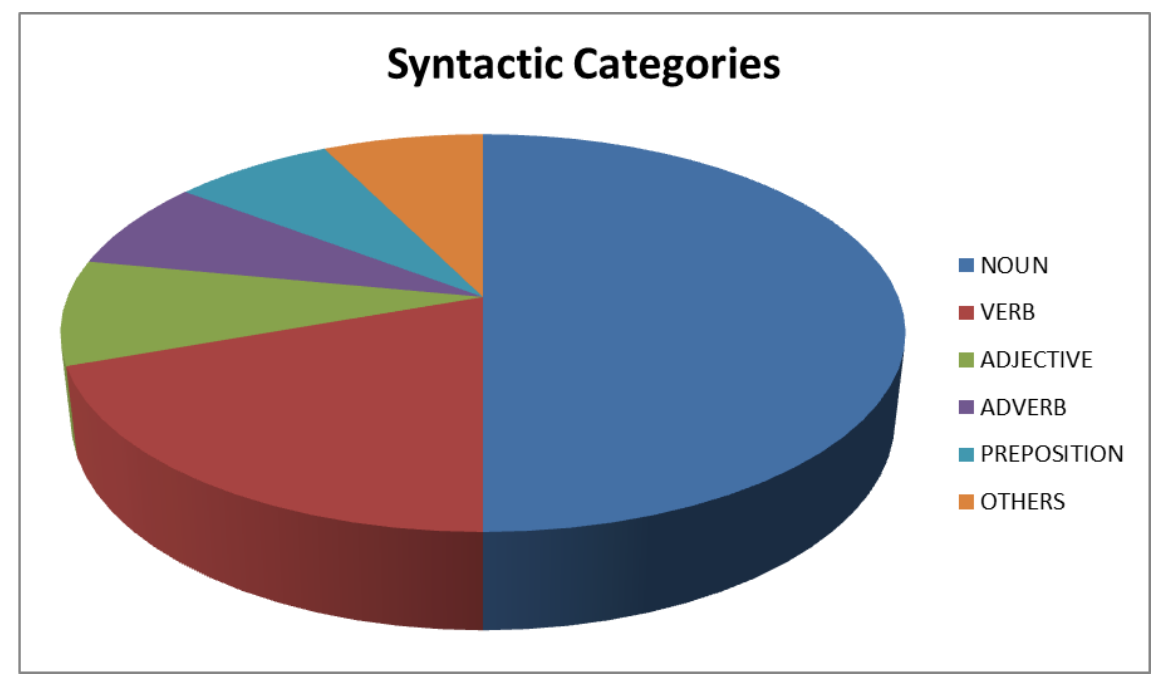

\section{Gambar 2. Diagram kosa kata yang terdapat dalam buku Radiographic Positioning} and Related Anatomy

Secara sederhana hasil proses klasifikasi kata dapat digambarkan melalui diagram pada gambar 2 di atas. Diagram tersebut menjelaskan bahawa kelas kata nomina menempati porsi yang paling banyak, diikuti oleh kelas kata verba, ajektiva, adverbial, dan preposisi. Selain kelas kata di atas juga ditemukan kategori lain-lain (others) yang cukup signifikan porsinya. Kategori ini berisi singkatan terminologi radiologi, potongan kata, dan lain-lain seperti konjungsi.

Kosa kata yang terkumpul kemudian akan digunakan pada penyusunan modul bahan ajar English for Specific Purposes untuk bidang radiologi. Kata-kata tersebut akan dirangkai berdasarkan tata bahasa yang ditemukan pada analisis dan kemudian disusun dalam bentuk teks dalam modul yang meliputi kompetensi berbahasa yaitu menyimak dan membaca, serta akan digunakan dalam berbicara dan menulis.

Dengan diperolehnya daftar kosa kata dan terminologi radiologi serta tata bahasa dan fitur linguistik pada kata-kata tersebut yang dibutuhkan dalam penyusunan bahan ajar English for Specific Purposes maka dapat disimpulkan bahwa penggunaan Linguistik Korpus sangat membantu dan cukup efektif dalam mempersiapkan bahan ajar ESP untuk Program Studi Radiologi. 


\section{UCAPAN TERIMA KASIH}

Ucapan terima kasih penulis haturkan kepada Kemenristek Dikti yang telah membiayai penelitian ini, kepada Politeknik Al Islam Bandung yang telah mendukung kegiatan ini, dan terimakasih tak terhingga kepada ketua LPPM dan staf yang selalu menginspirasi dan membantu penulis, serta pihak-pihak yang secara langsung ataupun tidak langsung terlibat dalam penelitian ini sehingga penelitian ini dapat berjalan dengan baik.

\section{DAFTAR PUSTAKA}

\section{Buku}

Biber, D., Conrad, S., \& Reppen, R. (1998). Corpus linguistics: investigating language structure and use. Cambridge: Cambridge University Press.

Bontrager, K.L., \& Lampignano, J.P. (2014). Textbook of Radiographic Positioning and Related Anatomy. Mosby.Inc

Gelderen, E. V. (2010). An introduction to the grammar of English (Revised edition). John Benjamins Publishing Company

Hunston, S. (2002). Corpora and Applied Linguistics. Cambridge: Cambridge University Press. Hutchinson, T., \& Waters, A. (1987). English for specific purposes. Cambridge university press.

McEnery, T., \& Hardie, A. (2011). Corpus linguistics: Method, theory and practice. Cambridge

\section{Jurnal Ilmiah} University Press.

Saragih, Erikson. (2014). Designing ESP Materials for Nursing Students Based On Needs Analysis. International Journal of Linguistics. Vol. 6, No. 4. 10.5296/ijl.v6i4.5983

Hanks, P. (1992). Lexicography: Theory and Practice. Dictionaries: Journal of the Dictionary Society of North America 14, 97-112. Dictionary Society of North America.

Roland, D. et.al. (2007). Frequency of Basic English Grammatical Structures: A Corpus Analysis. PMC. 57(3): 348-379. 